\title{
A Spatially Distributed Groundwater Metric for Describing Hydrologic Changes in a Regional Population of Wetlands North of Tampa Bay, Florida, from 1990 to 2015
}

Geoffrey Fouad ( $\nabla$ gfouad@monmouth.edu )

Monmouth University https://orcid.org/0000-0003-1221-8165

Terrie M. Lee

St Petersburg College

\section{Research Article}

Keywords: Palustrine wetland, Groundwater pumping, Upper Floridan aquifer, Potentiometric surface, LiDAR, Florida Posted Date: May 17th, 2021

DOI: https://doi.org/10.21203/rs.3.rs-525971/v1

License: (c) (i) This work is licensed under a Creative Commons Attribution 4.0 International License. Read Full License

Version of Record: A version of this preprint was published at Wetlands on October 28th, 2021. See the published version at https://doi.org/10.1007/s13157-021-01502-w. 


\section{Abstract}

A groundwater condition metric is presented and used to evaluate hydrologic changes in a regional population of wetlands in and around municipal well fields with large groundwater withdrawals. The approach compares a 26-year, monthly time series of groundwater potentiometric surfaces to light detection and ranging (LiDAR) land-surface elevations at 10,516 wetlands in a 1505-square-kilometer area. Elevation differences between the potentiometric surface and wetland land surface provide a flow direction (upward or downward) and a proxy for vertical hydraulic head difference in Darcy's groundwater flow equation. The resulting metric quantifies the groundwater condition at a wetland through time as the potential for groundwater to discharge upward into a wetland or for water in a wetland to leak downward to recharge the underlying aquifer. The potential for wetland leakage across the regional wetland population decreased by $33 \%$ in the 13 years after cutbacks in groundwater withdrawals (2003-2015) compared to years before cutbacks (1990-2002). Inside well field properties, wetland leakage potential decreased by $24 \%$. In the wet season month of September, wetlands with the potential to receive groundwater discharge increased to $21.6 \%$ of the regional population after cutbacks compared to $13.3 \%$ before cutbacks. When mapped across regional drainage basins, discharging wetlands formed spatial connections suggesting they play a critical role in generating streamflow.

\section{Introduction}

In Florida, protecting the ecology and hydrology of wetlands is a priority of water managers (see Florida Statute 373.414), and hundreds of freshwater wetlands are directly monitored in cooperation with federal, state, and local governmental agencies. Yet the large number of monitored wetlands is small compared to the overall wetland population, making it difficult to understand changes affecting wetlands at the landscape scale. Approximately a hundred thousand geographically isolated palustrine wetlands occur in the mid-peninsula of Florida alone (USFWS 2017). Most of these wetlands are small yet combined their area is comparable in size to the Everglades of South Florida (Haag and Lee 2010). Their scattered geographic distribution is key to another aspect of their importance: palustrine wetlands are the headwaters to most streams in central Florida (Ewel and Odum 1984; Haag and Lee 2010). The practical limits to monitoring a population of this magnitude requires that spatially-distributed hydrologic data, based on empirical measurements attributable to monitored and unmonitored wetlands alike, be used to assess the effects of groundwater withdrawals, climate, and land use on wetlands and streams in a region.

An empirical measurement that has been directly related to the hydrologic and ecologic status of wetlands in central Florida is the vertical hydraulic head difference driving saturated groundwater flow between the flooded wetland, shallow surficial aquifer, and deeper confined Upper Floridan aquifer (Lee et al. 2009; Metz 2011; Nilsson et al. 2013). In a detailed study of wetland water budgets, wetland leakage losses were directly proportional to the downward head difference, which equals the elevation difference between the wetland water surface and the potentiometric surface in the deeper Upper Floridan aquifer (Lee et al. 2009).

The vertical hydraulic head difference, which has units of length and can have an upward or downward direction, provides the basis for a surrogate metric: the elevation difference between the land-surface elevation inside the wetland and the potentiometric-surface elevation in the Upper Floridan aquifer. This distance was also shown to be proportional to wetland leakage (Lee et al. 2009). By using the land-surface elevation in a wetland as a substitute for a standing water elevation in the wetland, a comparable time series of elevation differences can be computed for any wetland with known land-surface elevations and a nearby well recording the potentiometric elevation in the Upper Floridan aquifer, regardless of whether the wetland is monitored or unmonitored, wet or dry, cypress or marsh, augmented or impacted (Lee et al. 2009). The method has been previously applied to selected wetlands and streams in the mantled karst terrain of central Florida to provide lines of evidence of (1) pumping impacts on wetland hydrology 
and vegetation (Metz 2011), (2) discharge/recharge frequency in wetlands (Nilsson et al. 2013), and (3) streamgroundwater interactions (Lee et al. 2010).

Using a potentiometric surface, the difference between a wetland's land-surface elevation and potentiometric elevation in the underlying aquifer could be calculated for a regional population of wetlands. A potentiometric surface maps the height to which water would rise in an aquifer if the overlying confining unit were removed (Bear 1979, p. 62), as in a tightly-cased well that penetrates a confined aquifer. Groundwater elevations measured in such wells can be interpolated to create a regional potentiometric surface. Potentiometric surfaces often represent groundwater conditions at a single point in time (see Bellino 2011; Ortiz 2011; Ameli and Creed 2017). However, a monitoring well network with enough synchronous measurements can be used to generate a time series of potentiometric surfaces (Lee and Fouad 2014), which in turn may be used to evaluate changes in wetland groundwater conditions. This approach has been applied to assess groundwater discharge into streams (Costelloe et al. 2015), but a similar study of wetlands was not found in the literature.

The present study uses a potentiometric surface time series based on Lee and Fouad (2014), and later extended by Lee and Fouad (2017), to calculate the difference between potentiometric elevations and land-surface elevations for 10,516 wetlands. The subsequent analysis applies the new metric of wetland groundwater condition to assess hydrologic changes in unmonitored wetlands before and after historic groundwater pumping cutbacks in an area north of Tampa Bay.

\section{Study Area}

The area north of Tampa Bay, locally known as the northern Tampa Bay area, extends about 50 kilometers north of metropolitan Tampa and about 30 kilometers onshore of the Gulf of Mexico (Fig. 1). In this low-lying terrain composed mostly of the Western Valley and Gulf Coastal Lowlands physiographic regions (White 1970), palustrine wetlands make up over 25 percent of the land area (USFWS 2017). In the mantled karst geologic setting, the transmissive carbonate formations of the Upper Floridan aquifer are overlain by a thin, semi-confining clay layer and topped by permeable sands and clayey sands (Sinclair et al. 1985). Groundwater from the Upper Floridan aquifer discharges upward along the coastline at springs that flow into the Gulf of Mexico and Tampa Bay.

Groundwater has the potential to flow upward and discharge into the surficial aquifer where the potentiometric-surface elevation in the Upper Floridan aquifer is above the elevation of the water table in the surficial aquifer, or more conservatively, where it is above the land-surface elevation. A discharging groundwater condition prevents water in wetlands from leaking downward and increases the potential for shallow palustrine wetlands to collect runoff and overflow to streams (Lee et al. 2010). Alternately, recharging groundwater conditions occur where the potentiometric surface in the Upper Floridan aquifer is below the water table in the surficial aquifer. With recharging conditions, groundwater in the surficial aquifer, and water in wetlands, flows downward toward the Upper Floridan aquifer. Pumping groundwater from the Upper Floridan aquifer lowers the potentiometric-surface elevation, which increases leakage losses from wetlands and reduces inundation (Metz 2011). Thus, in the permeable karst terrain of the study area, palustrine wetlands persist where they achieve a balance between the extent and duration of discharging and recharging groundwater conditions seasonally, annually, and over the long-term.

The study area has 11 well fields operated by Tampa Bay Water (eight of which have property boundaries) with a cumulative groundwater withdrawal rate that averaged about 568 million liters per day (mld) between 1990 and 2002 (see https://www.tampabaywater.org/water-supply-source-groundwater). Legally mandated cutbacks in well field pumping started in 2003 (Interlocal Agreement 1998, p. 75), decreasing the average withdrawal rate to below $341 \mathrm{mld}$ (SWFWMD 2015, p. 67). The response in the potentiometric-surface elevations in the Upper Floridan aquifer was 
recorded by 260 monitoring wells (Lee and Fouad 2014 Appendix 1), that were used to generate monthly-average potentiometric surfaces from 1990 to 2015 in Lee and Fouad (2017). The surfaces span a 1505-square-kilometer mapping area (Fig. 1) with 10,516 wetlands in the National Wetlands Inventory (USFWS 2017).

\section{Methods}

Potentiometric-surface elevations were from Lee and Fouad (2017) available at https://www.swfwmd.state.fl.us/resources/data-maps/hydrologic-data. Lee and Fouad (2017) applied a kriging approach developed in Lee and Fouad (2014) to interpolate monthly-average potentiometric surfaces in meters above/below the National Geodetic Vertical Datum of 1929 (NGVD 29) from 1990 to 2015. Monthly-average potentiometric surfaces were compared to wetland land-surface elevations derived from a gridded light detection and ranging (LiDAR) product provided by the Southwest Florida Water Management District (available upon request at https://www.swfwmd.state.fl.us/resources/data-maps/gis-maps-survey). The LiDAR data referenced the North American Vertical Datum of 1988 (NAVD 88), and were converted to meters above/below NGVD 29 (i.e. the same units as the potentiometric surfaces) using the National Geodetic Survey's VERTCON v2.1 grid (https://www.ngs.noaa.gov/PC_PROD/

\section{VERTCON/).}

The accuracy of LiDAR surveys in wetlands has been previously investigated (see Jones Edmunds \& Associates 2011; Hayes et al. 2018). Both studies confirmed that the LiDAR survey measured elevations below the tree canopy of forested wetlands. A comparison to conventionally surveyed points in wetlands further revealed that the LiDAR landsurface elevations met the National Standard for Spatial Data Accuracy (Jones Edmunds \& Associates 2011). The main sources of error were attributed to standing water and thick ground cover, both of which introduce an upward bias of about half a meter in LiDAR land-surface elevations in wetlands (Hayes et al. 2018). For this particular application, the upward bias makes the wetland groundwater condition metric a conservative estimator of discharging groundwater conditions when the potentiometric surface rises above the wetland land surface.

The wetland groundwater condition metric was calculated by first subtracting the LiDAR land surface from the monthly potentiometric surfaces (i.e. potentiometric surface - land surface). The difference was calculated using 1.524-meter (5-feet) grid cells (i.e. the same resolution as the LiDAR data). Potentiometric-surface elevations mapped using 100meter grid cells were assigned to the nearest 1.524-meter grid cell based on the Euclidean distance between grid cell centers. The difference was then calculated to generate a 1.524-meter grid in units of meters above/below land surface. The grid cells in a National Wetlands Inventory wetland were averaged to calculate groundwater condition for a given wetland. This calculation was repeated over 10,516 wetlands and 312 months to generate a wetland groundwater condition time series from 1990 to 2015. The time series of groundwater conditions was generated at each wetland, allowing results to be analyzed for the entire population, subpopulations, and various time periods.

A "predevelopment" potentiometric surface for the Upper Floridan aquifer was used to evaluate wetland groundwater conditions in the absence of pumping. The steady-state elevation of the potentiometric surface without groundwater pumping was modeled by Bush and Johnston (1988) and later digitized by Bellino (2011) using 250-meter grid cells. This potentiometric surface was used the same way as monthly potentiometric surfaces to calculate the hypothetical predevelopment wetland groundwater conditions at the 10,516 wetlands in the study area.

Population statistics, such as the median, were used to summarize annual wetland groundwater conditions. Monthly groundwater conditions were averaged for calendar years from 1990-2015 at each wetland. Annual averages across the wetlands were used to create box and whisker plots as in Tukey (1977, p. 39-43), with whiskers extending to the 
farthest non-outlier value (i.e. last data point within $1.5 \times$ (75th percentile -25 th percentile) from the box), box drawn to the 25th and 75th percentiles, and bar in the box indicating the median value. Annual box and whisker plots of wetland groundwater conditions were compared to the predevelopment condition. Box and whisker plots were also generated using monthly data for May, to reflect dry season groundwater conditions, and September, to reflect wet season groundwater conditions.

Wetland groundwater conditions were classified as discharging or as recharging in one of four recharge categories (Table 1). Recharge categories are increasing distances of the potentiometric surface below land surface, corresponding to a greater potential for wetland leakage. The percentage of wetlands in each category was calculated using annual average, May, and September data and displayed using pie charts.

Table 1

Categories of discharging and recharging groundwater conditions. Discharging category (-) indicates the potentiometric surface is at or above land surface

\begin{tabular}{|llll|}
\hline Category & Type & Map color & Distance of the potentiometric surface below land surface in meters (feet) \\
\hline 1 & Discharging & Dark blue & - \\
\hline 2 & Recharging & Light blue & $>0$ to 1.524 meters $(>0$ to 5 feet $)$ \\
\hline 3 & Recharging & Yellow & $>1.524$ to 3.048 meters $(>5$ to 10 feet $)$ \\
\hline 4 & Recharging & Orange & $>3.048$ to 4.572 meters $(>10$ to 15 feet $)$ \\
\hline 5 & Recharging & Red & $>4.572$ meters $(>15$ feet $)$ \\
\hline
\end{tabular}

The percentage of wetlands in each groundwater condition category was compared for pre- (1990-2002) and postcutback (2003-2015) time periods of well field groundwater pumping. The average percentage of wetlands in a groundwater condition category was assessed for statistically significant changes before and after cutbacks using a $t$ test following the procedure in Casella and Berger (2002, p. 409-410). A $t$-test assumes the two samples have equal variances and are drawn from a normal distribution. However, the test is largely robust to the latter assumption, and may be applied on non-normally distributed data (Posten 1984). The assumption of equal variances was assessed using an F-test for normally distributed data (i.e. Anderson-Darling normality test $p$-value $>0.05$ ) or Levene's test for non-normally distributed data (i.e. Anderson-Darling normality test $p$-value $\leq 0.05$ ). If the variances were not equal based on either the F-test or Levene's test (i.e. $p$-value $\leq 0.05$ ), then estimates of the variance in the pre- and postcutback samples were used in a Welch's $t$-test for unequal variances (Welch 1951).

Wetland groundwater conditions were mapped to show how conditions varied across the region. Using the colors and categories described in Table 1, the maps display wetland groundwater conditions for the predevelopment potentiometric surface, and the average May, September, and annual conditions during pre- (1990-2002) and postcutback (2003-2015) time periods.

\section{Results}

Wetland groundwater conditions indicated less wetland recharge after cutbacks than before cutbacks (Fig. 2). Median groundwater conditions averaged 2.1 meters below land surface (category 3) before cutbacks, compared with 1.4 meters below land surface (category 2) after cutbacks, an upward change in the metric of $33 \%$. A smaller upward change of $24 \%$ occurred in the median groundwater condition of wetlands inside well fields (not shown), which averaged 2.1 meters below land surface and 1.6 meters below land surface before and after cutbacks, respectively. For 12 of the 13 years before cutbacks, the median annual groundwater condition was between 1.524 meters ( 5 feet) and 
3.048 meters (10 feet) below land surface for the 10,516 wetlands. After cutbacks, median annual groundwater conditions stayed within 0 to 1.524 meters ( 5 feet) below land surface for 9 of 13 years. The interquartile range (see the boxes in Fig. 2) decreased following cutbacks, as did the range of the whiskers (non-outlier minimum and maximum). The reduced range in non-outlier extreme values resulted in higher minimum and lower maximum groundwater conditions after cutbacks. Non-outlier minima were normally between 6.096 meters (20 feet) and 7.62 meters (25 feet) below land surface before cutbacks ( 9 of 13 years). After cutbacks, non-outlier minima ranged from 3.048 meters (10 feet) to 5.4864 meters (18 feet) for 9 of 13 years. The only downward trend occurred for non-outlier maxima, which averaged 2.7 meters above land surface before cutbacks and 2.2 meters above land surface after cutbacks.

Annual average conditions after groundwater pumping cutbacks were closer to predevelopment conditions than the years prior to cutbacks (Fig. 2). Rounding to the nearest tenth, the average of post-cutback medians was the same as the predevelopment median (1.4 meters below land surface), whereas the pre-cutback time period had an average $50 \%$ lower than the predevelopment median. Post-cutback medians were surrounded by interquartile ranges (boxes) with an average $10 \%$ different than predevelopment, as opposed to a 19\% difference for pre-cutback years. Pre-cutback interquartile ranges and extremes (whiskers) were larger than predevelopment in 12 of 13 years. The opposite occurred after cutbacks in which 12 of 13 years had smaller interquartile ranges and extremes than predevelopment. Despite the difference in ranges, the pre-cutback period had more similar non-outlier maxima (upper whiskers) to predevelopment than the post-cutback period. The non-outlier minima, however, were closer to predevelopment minima after cutbacks than before cutbacks. The post-cutback period had multiple years in which box plot statistics from the non-outlier minimum to the $75^{\text {th }}$ percentile (top of box) were all greater than predevelopment (see 2003 to 2004 and 2014 to 2015). Prior to cutbacks, this only occurred once in 1998. The post-cutback period did have some years of lower groundwater conditions in which the $75^{\text {th }}$ percentile was similar to the predevelopment median (see 2006 to 2009 ). This occurred in many years before cutbacks, and was particularly exaggerated in 2000 and 2001.

Wetlands also showed less potential for recharge during the dry season after cutbacks compared with before cutbacks (Fig. 3a). Median groundwater conditions in May remained in category 3 on average but rose from 2.6 to 1.9 meters below land surface, a $27 \%$ upward change in the years after groundwater pumping cutbacks compared to the years before cutbacks. Wetlands inside well fields (not shown) experienced a smaller upward change of $22 \%$ in median groundwater conditions for the month of May after cutbacks. Returning to the entire wetland population, median May values were all 1.524 meters ( 5 feet) or more below land surface before cutbacks, whereas 6 of 13 years after cutbacks rose above this threshold.

September groundwater conditions showed the largest pre- versus post-cutback reduction in recharging conditions at wetlands, and the greatest increase in the potential for wetlands to receive groundwater discharge (Fig. 3b). The median groundwater condition averaged 1.0 meters below land surface after cutbacks (category 2), a $41 \%$ increase compared with pre-cutback conditions averaging 1.7 meters below land surface (category 3 ). For wetlands in well fields (not shown), the same statistic increased $31 \%$ after cutbacks. The entire wetland population had median September values of 1.524 meters (5 feet) or more below land surface in 9 of 13 years before cutbacks. Only one year (2007) fell below this threshold after cutbacks.

Interquartile ranges and extremes followed similar patterns in May (Fig. 3a) and September (Fig. 3b). Ranges around the medians (i.e. boxes and whiskers) decreased after groundwater pumping cutbacks. Non-outlier minima (lower whiskers) increased after cutbacks to the point where minimum groundwater conditions after cutbacks were regularly above the highest non-outlier minimum before cutbacks in May (7 of 13 years) and September (9 of 13 years). Nonoutlier maxima (upper whiskers) exhibited a slight decline following cutbacks. For example, September maxima 
exceeded 2.7432 meters ( 9 feet) above land surface in 12 of 13 years before cutbacks and only one year (2004) after cutbacks.

The percentages of wetlands in each groundwater condition category changed markedly in the May, September, and annual time periods after pumping cutbacks (Fig. 4). The percentage of wetlands in the two highest recharge categories (4 and 5, orange and red, respectively) decreased in most years after cutbacks, except for drought years from 2007 to 2009 . Before cutbacks, $41 \%$ of the regional wetland population was in the two highest recharge categories in May, on average. The May average decreased to $27 \%$ after cutbacks. The percentage of wetlands in the lowest recharge (light blue) and discharging (dark blue) categories increased after cutbacks, particularly for September groundwater conditions. The average percentage of wetlands in these two categories in September increased from $46 \%$ of the regional population before cutbacks to $65 \%$ after cutbacks.

The percentage change of wetlands in different groundwater condition categories was statistically significant for annual, May, and September time intervals (Table 2). The number of wetlands with groundwater conditions more than 3.048 meters (10 feet) below land surface (categories 4 and 5) significantly decreased after cutbacks. For example, the average percentage of wetlands with groundwater conditions 4.572 meters (15 feet) below land surface in May significantly decreased from $20.7 \%$ before cutbacks to $11.6 \%$ after cutbacks ( $p$-value $=0.00$ ), while the percentage of wetlands in the lowest recharge category significantly increased in May and for all other time intervals $(p$-value $\leq$ 0.01). The percentage of wetlands with a groundwater discharge condition increased for all time intervals, although the increase was only statistically significant in the wet season month of September ( $p$-value $=0.01)$. Annual average changes were compared to predevelopment conditions, which were generally more similar to the post-cutback time period (see the two highest recharge categories and discharge category). The average difference from the predevelopment categories was smaller for the post-cutback time period (4.7\%) than the pre-cutback time period $(6.1 \%)$.

Table 2 Pre- and post-cutback changes in the percentage of 10,516 wetlands in groundwater condition categories. Statistically significant changes are evaluated using a $t$-test and $p$-value $\leq 0.05$. Recharge categories are expressed in meters $(\mathrm{m})$ and feet $(\mathrm{ft})$ below land surface 


\begin{tabular}{|c|c|c|c|c|c|c|}
\hline \multirow{4}{*}{$\begin{array}{l}\text { Time } \\
\text { interval }\end{array}$} & \multirow{4}{*}{$\begin{array}{l}\text { Time period and } \\
\text { statistical change }\end{array}$} & \multicolumn{5}{|c|}{ Percentage of wetlands in groundwater condition category } \\
\hline & & \multirow{3}{*}{$\begin{array}{l}\begin{array}{l}\text { Discharge } \\
\text { category }\end{array} \\
\text { At or above } \\
\text { land surface }\end{array}$} & \multirow{2}{*}{\multicolumn{4}{|c|}{$\begin{array}{l}\text { Recharge category } \\
\text { (distance below land surface) }\end{array}$}} \\
\hline & & & & & & \\
\hline & & & $\begin{array}{l}>0-1.524 \\
\mathrm{~m}(>0-5 \mathrm{ft})\end{array}$ & $\begin{array}{l}>1.524-3.048 \\
m(>5-10 \mathrm{ft})\end{array}$ & $\begin{array}{l}>3.048-4.572 \\
\mathrm{~m}(>10-15 \mathrm{ft})\end{array}$ & $\begin{array}{l}>4.572 \mathrm{~m} \\
(>15 \mathrm{ft})\end{array}$ \\
\hline \multirow[t]{5}{*}{ Annual } & Predevelopment & 19.7 & 33.3 & 30.7 & 12.1 & 4.2 \\
\hline & Pre & 9.2 & 28.5 & 30.8 & 17.0 & 14.5 \\
\hline & Post & 12.1 & 42.1 & 27.5 & 11.1 & 7.2 \\
\hline & Significant change? & No & Yes (up) & No & Yes (down) & $\begin{array}{l}\text { Yes } \\
\text { (down) }\end{array}$ \\
\hline & $p$-value & 0.09 & 0.00 & 0.09 & 0.00 & 0.00 \\
\hline \multirow[t]{4}{*}{ May } & Pre & 6.7 & 21.5 & 30.7 & 20.5 & 20.7 \\
\hline & Post & 7.9 & 33.2 & 32.4 & 15.0 & 11.6 \\
\hline & Significant change? & No & Yes (up) & No & Yes (down) & $\begin{array}{l}\text { Yes } \\
\text { (down) }\end{array}$ \\
\hline & $p$-value & 0.36 & 0.01 & 0.25 & 0.01 & 0.00 \\
\hline \multirow[t]{4}{*}{ September } & Pre & 13.3 & 33.0 & 27.3 & 14.3 & 12.1 \\
\hline & Post & 21.6 & 43.4 & 21.3 & 8.5 & 5.2 \\
\hline & Significant change? & Yes (up) & Yes (up) & Yes (down) & Yes (down) & $\begin{array}{l}\text { Yes } \\
\text { (down) }\end{array}$ \\
\hline & $p$-value & 0.01 & 0.00 & 0.01 & 0.00 & 0.00 \\
\hline
\end{tabular}

Extensive spatial differences occurred in the average annual wetland groundwater condition before and after groundwater pumping cutbacks (Fig. 5). Some notable patterns include the transition to lower recharge categories (e.g. from orange to yellow, or yellow to light blue) at hundreds of wetlands in and around Cross Bar Ranch, South Pasco, and Eldridge Wilde well fields. In Cross Bar Ranch, wetlands along the southern border changed from yellow to light blue. Wetlands southeast of Cross Bar Ranch changed similarly from yellow to light blue, and another area of wetlands east of Cross Bar Ranch changed from orange to yellow. Wetlands throughout South Pasco changed from orange to light blue, reducing their recharge potential by two categories. Eldridge Wilde wetlands transitioned from orange to yellow and yellow to light blue both in the well field and in a halo around the well field.

A contiguous chain of wetlands with discharging (dark blue) groundwater conditions appeared along regional streams after groundwater pumping cutbacks (Fig. 5). A 10-15-mile stretch of wetlands along the Pithlachascotee River changed to discharging conditions between North Pasco and Starkey well fields. A similar transition occurred along nearly the entire main stem of the Anclote River at the southern border of Starkey well field. Discharging groundwater conditions increased at wetlands in the headwaters of these stream drainage basins (e.g. east of Starkey well field). Headwater wetlands also transitioned to the lowest recharge category (light blue) in Starkey and Cypress Creek well fields, and an area draining into Double Branch south of Cosme well field.

Wetland groundwater conditions after pumping cutbacks more closely resembled predevelopment conditions than precutback conditions (Fig. 5). Discharging groundwater conditions were prevalent at wetlands in the Pithlachascotee and 
Anclote River drainage basins under predevelopment conditions, and this pattern returned along the main stems of these rivers after pumping cutbacks. Predevelopment conditions covered Cypress Creek well field with discharging wetlands, which transitioned to the lowest recharge category (light blue) after cutbacks. Wetlands in Eldridge Wilde well field were similarly split between light blue and yellow recharge categories both after cutbacks and under predevelopment conditions. Recharging conditions in Cross Bar Ranch well field were similar in predevelopment and post-cutback periods, with the notable exception of some lower recharge conditions after cutbacks (e.g. along the southern border of the well field). In South Pasco well field, some wetlands had a lower recharge category (light blue) after cutbacks than for predevelopment conditions (yellow).

For the month of May, wetlands with discharging groundwater conditions (dark blue), a category which had been absent inside well field properties before cutbacks, occurred in parts of Cypress Creek and Morris Bridge well fields after cutbacks (Fig. 6). A connected chain of discharging wetlands formed along the channel of Cypress Creek inside the southern end of the well field and continued south of the well field. In Morris Bridge well field, the discharging groundwater conditions occurred at wetlands draining into the Hillsborough River. Other drainage systems experienced lower recharge conditions after cutbacks in May. For example, headwater wetlands and tributaries to the Anclote River at the southern border of Starkey well field changed to lower recharge categories after cutbacks. Lower recharge conditions in May were also prevalent in Eldridge Wilde, South Pasco, and Section 21 well fields.

For the month of September, post-cutback changes were characterized by an increase in discharging (dark blue) conditions along stream channels, extending upstream to headwater wetland areas, and a decrease in recharge conditions (Fig. 7). Wetlands along the entire main stem of the Anclote River at the southern border of Starkey well field shifted to discharging conditions after cutbacks. Discharging wetland groundwater conditions extended along tributaries to the south of Anclote River and occurred at headwater wetlands to the east. Discharging conditions also grew in headwater wetlands to the Pithlachascotee River and Fivemile Creek east of North Pasco well field. Headwater wetlands to Cypress Creek, both inside the well field and extending to the east of the well field, changed to the lowest recharge category (light blue) after cutbacks. The lowest recharge category (light blue) replaced the orange recharge category after cutbacks in Eldridge Wilde and South Pasco well fields. A similar shift in two recharge categories from the red to the yellow category occurred after cutbacks in Section 21 well field. Wetland groundwater conditions in Cross Bar Ranch well field also shifted to lower recharge categories (e.g. yellow to light blue changes) after cutbacks.

\section{Discussion}

Wetland groundwater condition proved to be a versatile hydrologic metric that was comparable and quantifiable in a large wetland population, and assessable monthly over multiple decades. The metric was useful for assessing the synchronous condition in an entire wetland population at a regional scale, yet granular enough to describe the monthly condition of an individual wetland through time. Here we use it to describe 10,516 wetlands spread over a geographic area of 1505 square kilometers and parts of six stream drainage basins. The wetlands are in and around 11 municipal well fields and their condition is described monthly for 26 years that bracket large cutbacks in groundwater pumping. The same approach could be extended to describe the groundwater condition of wetlands distributed over an even larger geographic area, such as mid-peninsula Florida.

With a geographic area of 59,947 square kilometers, including 13,001 square kilometers of wetland area (Haag and Lee 2010), freshwater wetlands of central Florida cover an area that rivals the prairie potholes of the central United States (22,272 square kilometers; USFWS 2017) or Everglades National Park (2200 square kilometers; Haider et al. 2020). Most of the wetlands are unmonitored and have a groundwater condition that is impacted by the elevation of the potentiometric surface. The Upper Floridan aquifer underlies all of central Florida, is mostly thinly confined, and, as the 
principal source of freshwater, is intensively pumped (Haag and Lee 2010; Marella 2020). Wetland groundwater condition offers an approach to monitoring such a large population of wetlands. The potentiometric surface in the Upper Floridan aquifer is mapped over much of north-central Florida and parts of southern Georgia, albeit synoptically in May and September of each year (e.g. Bellino 2011 and https://geodata.dep.state.fl.us/datasets/upper-floridanaquifer-potentiometric-surface-september-2017). Wetlands throughout central Florida could be assessed at this biannual frequency, or more often if the mapping frequency were increased using data from continuously monitored wells. The US Geological Survey, water management districts, and other state and regional water resources agencies collect continuous data that could be used for this purpose (see for example https://www.swfwmd.state.fl.us/

resources/data-maps/hydrologic-data and https://www.sjrwmd.com/data/hydrologic/). National Wetlands Inventory data (USFWS 2017) and LiDAR data (see https://www.floridadisaster.org/

dem/ITM/geographic-information-systems/lidar) exist statewide, making the method extendable to a larger geographic area.

Describing wetland groundwater conditions in monitored and unmonitored wetlands alike revealed regional impacts to wetlands from historic well field pumping that had gone unidentified using only monitored wetlands. The timing, location, and changes in wetland groundwater conditions indicated wetlands well beyond the boundaries of well field properties were being affected by pumping prior to cutbacks. Pumping cutbacks were associated with statistically significant improvements in groundwater condition at wetlands both inside and outside of well fields, where improvement is viewed as a change in the groundwater condition category resulting in less wetland leakage. Compared to the entire wetland population, pumping cutbacks yielded smaller changes in the groundwater condition of the wetlands inside well fields, where more localized effects of groundwater pumping were focused (see for example Metz 2011). Nonetheless, wetlands inside well fields also experienced significant improvement in groundwater conditions after cutbacks (Lee and Fouad 2018, Table 10).

Wetland groundwater condition, when averaged annually, had the advantage of being comparable to a benchmark, namely the predevelopment wetland groundwater conditions. Following cutbacks, the median, interquartile range, and extremes of annual average groundwater conditions in the wetland population began to resemble their predevelopment counterpart with one notable exception, the distribution maxima (Fig. 2). Results showed the aquifer potentiometric surface no longer reached as high an elevation above some wetlands as it did under predevelopment conditions, or even the pre-cutback era when well field pumping was greatest. This downward trend in the highest potentiometric surface elevations could be a regional expression of less infiltration to groundwater due to an increase in impervious surfaces in the study area (Weng and Pu 2013). A study by Paynter et al. (2011) found that urbanization reduces groundwater flow to lakes in this same area. Increasing groundwater withdrawals outside of well fields over the same period probably contributed to this effect as well (Geurink and Basso 2013, Fig. 2.70; Marella 2020). Pumping cutbacks on the well fields presumably would have created additional discharging and low-recharging wetlands in the absence of this declining trend.

Changes in the average May groundwater condition of the wetland population showed region-wide improvement after pumping cutbacks (Table 2). Wetlands that chronically reach the highest recharge categories in the dry season are at the most risk of irremediable damage due to desiccation, oxidation of hydric soils, and subsidence (Tihansky 1999; Lee et al. 2009; Metz 2011). Pumping cutbacks reduced the percentage of all wetlands in the two highest recharge categories in May, improving the groundwater condition of thousands of wetlands. Wetlands inside well fields showed less change and greater potential for recharge than wetlands outside well fields in May (Fig. 6), and their condition will continue to require attention, particularly because well field groundwater withdrawals are typically greatest in the dry season when water demands peak (TBW 2013, p. 101).

Page $10 / 22$ 
In the month of September, the number of wetlands primed by their groundwater condition to overflow to streams substantially increased following pumping cutbacks. Pumping cutbacks reduced the recharge potential of a significant percentage of wetlands while significantly increasing the percentage of wetlands with a groundwater discharge condition (Table 2). The number of discharging wetlands located inside well fields increased, but by less than outside well fields (Fig. 7). September groundwater conditions showed larger changes following cutbacks than either annual and May changes. This response may reflect an increased reliance on surface water (reservoirs) to meet public demand during the wet season in post-cutback years, and a reduced need for groundwater pumping (TBW 2013, p. 101).

Changes in wetland groundwater condition provide a logical mechanism to explain flow reductions in area streams before pumping cutbacks, and the recovery of flow rates since, as documented for the Anclote and Pithlachascotee Rivers (Heyl et al. 2010, p. 27; Leeper et al. 2018, pp. 30-31). Wetlands in central Florida typically reach their highest standing water levels and largest flooded areas in September (Haag and Pfeiffer 2012; Nilsson et al. 2013; Cameron et al. 2020). This coincides with a large percentage of discharging wetlands (Fig. 4c). Because wetlands with groundwater discharge conditions slowly gain groundwater, and cannot lose water through leakage, it increases their probability of overflowing to tributary streams during the wet season (Haag and Lee 2010; Lee et al. 2010; Ameli and Creed 2017).

Mapping wetland groundwater conditions, especially in September, revealed a consistent pattern of wetlands with discharging groundwater conditions being located adjacent to and in the headwaters of three principal streams, and their tributaries (Fig. 7). This pattern indicates the groundwater condition of these wetlands plays a seasonal role in generating flow to the streams. In Florida, depressional wetlands in the state's interior have long been recognized as headwaters and therefore hydraulically connected to rivers (Livingston 1991), including the four major rivers originating in central Florida (Brown 1984), even though the physics based metrics to argue it were lacking. Modeling studies increasingly show this to be the case (see for example Lee et al. 2010), and more recently, outflows from depressional wetlands to stream channels have been mapped using LiDAR data and verified in the field (McDonough et al. 2015). Spatial patterns of wetland groundwater condition provide an independent line of evidence that can be used to examine the connectivity of wetlands to streams. It also provides a corroborating line of evidence to use with other wetland metrics to argue the location of stream channels carrying ephemeral flows from wetlands downstream.

\section{Conclusions}

Wetland groundwater condition is a versatile metric that shows promise as a way to assess the hydrologic condition of large wetland populations in Florida. The metric allows the groundwater condition of thousands of wetlands to be assessed synoptically at a watershed scale, or monthly over multiple decades. When the metric is averaged annually for individual wetlands or a population of wetlands, the metric is comparable to a management target of predevelopment wetland groundwater conditions. Tracking the metric monthly over 26 years gave a tenable approach for assessing hydrologic impacts of regional well field pumping on the hydrology of more than 10,000 wetlands in parts of six watersheds, and its implicit effects on regional streamflow.

The potential for wetlands in the regional population to leak decreased by $33 \%$ in the latter 13 years of the study compared to the 13 years before groundwater pumping cutbacks. Wetland leakage decreased less in well field properties (24\%) where the effects of pumping are localized. Discharging groundwater conditions were notably different in the wet season month of September, in which the percentage of discharging wetlands in the entire population increased from $13.3 \%$ before cutbacks to $21.6 \%$ after cutbacks. When mapped across regional drainage

Page $11 / 22$ 
basins, discharging palustrine wetlands aligned with stream channels suggesting they play a critical role in generating streamflow.

The groundwater metric proposed here may be applied to other study areas where the potentiometric surface is near land surface and influences wetland-groundwater interactions. Wetland groundwater condition is a new and independent line of evidence with which to infer surface water flows between wetlands. Stream flows between sequentially aligned palustrine wetlands with discharging conditions are a likely source of seasonal flow to principal rivers located miles away. The overflow of palustrine wetlands should be investigated further in the field to provide additional lines of evidence as to the role of palustrine wetlands in contributing flow to area streams.

\section{Declarations}

\section{Acknowledgments}

We thank Tampa Bay Water for funding this research. Tampa Bay Water staff, Erin Hayes and Chris Shea, supplied helpful data and information on the study area. Warren Hogg managed the contract at Tampa Bay Water, and was instrumental in the funding process. The Southwest Florida Water Management District is kindly hosting the data generated by this work and prior projects that made this work possible. For that, we thank Margit Crowell and Axel Griner.

\section{Funding}

The work presented here was conducted for a research contract funded by Tampa Bay Water.

\section{Conflict of Interest}

The authors received funding to perform this work from Tampa Bay Water, the regional water supplier responsible for groundwater withdrawals in well fields. This in no way shaped the results of this work.

\section{Ethics Approval}

Not applicable

\section{Consent to Participate}

Not applicable

\section{Consent for Publication}

Not applicable

\section{Availability of Data}

The data analyzed in this study is available at:

http://www4.swfwmd.state.fl.us/downloads/WetlandGroundwaterConditions.zip

\section{Code Availability}

Not applicable 


\section{Authors' Contributions}

GF conducted the analysis, prepared the manuscript, and contributed to research design.

TML designed the research, contributed original drafts for parts of the manuscript, and supplied in-depth revisions to the manuscript.

\section{References}

Ameli AA, Creed IF (2017) Quantifying hydrologic connectivity of wetlands to surface water systems. Hydrol Earth Syst Sc 21:1791-1808. https://doi.org/10.5194/hess-21-1791-2017

Bear J (1979) Hydraulics of groundwater. McGraw Hill, New York

Bellino JC (2011) Digital surfaces and hydrogeologic data for the Floridan aquifer system in Florida and in parts of Georgia, Alabama, and South Carolina. US Geological Survey Data Series 584. https://doi.org/10.3133/ds584

Brown SL (1984) The role of wetlands in the Green Swamp. In: Ewel KC, Odum HT (eds) Cypress swamps. University Press of Florida, Gainesville, pp 405-415.

Bush PW, Johnston RH (1988) Ground-water hydraulics, regional flow, and ground-water development of the Floridan aquifer system in Florida and in parts of Georgia, South Carolina, and Alabama. US Geological Survey Professional Paper 1403-C, 80 p. https://doi.org/10.3133/pp1403C

Cameron CR, Hancock MC, Carr DW, Hurst MK, Campbell DE, Venning TJ, Tara PD, Holzwart KR (2020) Hydroperiods of cypress domes in west-central Florida, USA. Wetlands. https://doi.org/10.1007/s13157-020-01329-x

Casella G, Berger RL (2002) Statistical inference. Duxbury Press, Pacific Grove, California

Costelloe JF, Peterson TJ, Halbert K, Western AW, McDonnell JJ (2015) Groundwater surface mapping informs sources of catchment baseflow. Hydrol Earth Syst Sc 19:1599-1613. https://doi.org/10.5194/hess-19-1599-2015

Ewel KC, Odum HT (1984) Cypress swamps. University Press of Florida, Gainesville

Geurink JS, Basso R (2013) Development, calibration, and evaluation of the integrated northern Tampa Bay hydrologic model. Tampa Bay Water and Southwest Florida Water Management District Report, 916 p.

https://tampabaywater.sharefile.com/d-s5e38f1f0e0c41ac9

Haag KH, Lee TM (2010) Hydrology and ecology of freshwater wetlands in central Florida - A primer. US Geological Survey Circular 1342, 138 p. https://doi.org/10.3133/cir1342

Haag KH, Pfeiffer WR (2012) Flooded area and plant zonation in isolated wetlands in well fields in the northern Tampa Bay region, Florida, following reductions in groundwater-withdrawal rates. US Geological Survey Scientific Investigations Report 2012-5039,

49 p. https://doi.org/10.3133/sir20125039

Haider S, Swain E, Beerens J, Petkewich M, McCloskey B, Henkel H (2020) The Everglades Depth Estimation Network (EDEN) surface-water interpolation model, version 3. US Geological Survey Scientific Investigations Report 2020-5083, 31 p. https://doi.org/10.3133/sir20205083

Page $13 / 22$ 
Hayes E, Fouad G, Lee TM (2018) LiDAR accuracy assessment in 305 wetlands. In Proc. of the American Water Resources Association Spring Specialty Conference, Orlando, Florida, April 22-25, 2018

Heyl MG, Munson AB, Hood J, Morales J, Kelly M (2010) Anclote River system recommended minimum flows and levels. Southwest Florida Water Management District Report, 207 p.

https://www.swfwmd.state.fl.us/sites/default/files/documents-and-reports/reports/

Anclote_MFL_Final_0.pdf

Interlocal Agreement (1998) Amended and restated interlocal agreement reorganizing the West Coast Regional Water Supply Authority. State of Florida legal document, 116 p. https://ufdc.ufl.edu/WL00003978/00001

Jones Edmunds \& Associates (2011) Wetland hydrologic analysis: Wetland classification and basin character study. Southwest Florida Water Management District Report Certificate of Authorization \#1841, 59 p.

Lee TM, Fouad GG (2014) Creating a monthly time series of the potentiometric surface in the Upper Floridan aquifer, northern Tampa Bay area, Florida, January 2000-December 2009. US Geological Survey Scientific Investigations Report 2014-5038, 26 p. https://doi.org/10.3133/sir20145038

Lee TM, Fouad GG (2017) Extending the monthly time series of the potentiometric surface in the Upper Floridan aquifer, northern Tampa Bay area, Florida, January 1990-December 2015. Tampa Bay Water Report, 30 p. https://www.swfwmd.state.fl.us/sites/default/files/

medias/documents/SummaryReport_TBW2017.pdf

Lee TM, Fouad GG (2018) Changes in wetland groundwater conditions in the Northern Tampa Bay area from 1990 to 2015. Tampa Bay Water Report, 50 p.

https://www.swfwmd.state.fl.us/sites/default/files/medias/documents/Changes_Wetland_GW_Conditions_NTB_1990$2015 \% 20 \% 286 \% 29 . p d f$

Lee TM, Haag KH, Metz PA, Sacks LA (2009) The comparative hydrology, water quality, and ecology of selected natural and augmented freshwater wetlands in west-central Florida. US Geological Survey Professional Paper 1758,152 p. https://doi.org/10.3133/pp1758

Lee TM, Sacks LA, Hughes JD (2010) Effect of groundwater levels and headwater wetlands on streamflow in the Charlie Creek basin, Peace River watershed, west-central Florida. US Geological Survey Scientific Investigations Report 2010-5189, 77 p. https://doi.org/10.3133/sir20105189

Leeper D, Herrick G, Basso R, Heyl M, Ghile Y, Flannery M, Hinkle T, Hood J, Williams G (2018) Recommended minimum flows for the Pithlachascotee River. Southwest Florida Water Management District Report, $144 \mathrm{p}$.

https://www.swfwmd.state.fl.us/sites/

default/files/documents-and-reports/reports/Pith_MFLs_2018-03-22.pdf

Livingston RJ (1991) The rivers of Florida. Springer, New York

Marella RL (2020) Water withdrawals, uses, and trends in Florida, 2015. US Geological Survey Scientific Investigations Report 2019-5147, 52 p. https://doi.org/10.3133/sir20195147 
McDonough OT, Lang MW, Hosen JD, Palmer MA (2015) Surface hydrologic connectivity between Delmarva bay wetlands and nearby streams along a gradient of agricultural alteration. Wetlands 35:41-53.

https://doi.org/10.1007/s13157-014-0591-5

Metz PA (2011) Factors that influence the hydrologic recovery of wetlands in the northern Tampa Bay area, Florida. US Geological Survey Scientific Investigations Report 2011-5127, 58 p. https://doi.org/10.3133/sir20115127

Nilsson KA, Rains MC, Lewis DB, Trout KE (2013) Hydrologic characterization of 56 geographically isolated wetlands in west-central Florida using a probabilistic method. Wetl Ecol Manag 21:1-14. https://doi.org/10.1007/s11273-012-92751

Ortiz AG (2011) Potentiometric surface of the Upper Floridan aquifer, west-central Florida, May 2011. US Geological Survey Scientific Investigations Map 3183. https://doi.org/10.3133/sim3183

Paynter S, Nachabe M, Yanev G (2011) Statistical changes of lake stages in two rapidly urbanizing watersheds. Water Resour Manag 25:21-39. https://doi.org/10.1007/s11269-010-9685-x

Posten HO (1984) Robustness of the two-sample t-test. In: Rasch D, Tiku ML (eds) Robustness of statistical methods and nonparametric statistics. Springer, Dordrecht, pp 92-99. https://doi.org/10.1007/978-94-009-6528-7_23

Sinclair WC, Stewart JW, Knutilla RL, Gilboy AE, Miller RL (1985) Types, features, and occurrence of sinkholes in the karst of west-central Florida. US Geological Survey Water-Resources Investigations Report 85-4126, 81 p. https://doi.org/10.3133/wri854126

Southwest Florida Water Management District (SWFWMD) (2015) Regional water supply plan: Tampa Bay planning region. SWFWMD, Brooksville, Florida

Tampa Bay Water (TBW) (2013) Tampa Bay Water: Long-term master water plan 2013. TBW, Clearwater, Florida

Tihansky AB (1999) Sinkholes, west-central Florida. In: Galloway D, Jones DR, Ingebritsen SE (eds) Land subsidence in the United States. US Geological Survey Circular 1182, pp 121-140. https://doi.org/10.3133/cir1182

Tukey JW (1977) Exploratory data analysis. Addison-Wesley, Reading, Massachusetts

US Fish and Wildlife Service (USFWS) (2017) National Wetlands Inventory. USFWS, Washington, DC. https://www.fws.gov/wetlands

Welch BL (1951) On the comparison of several mean values: An alternative approach. Biometrika 38:330-336. https://doi.org/10.2307/2332579

Weng F, Pu R (2013) Mapping and assessing of urban impervious areas using multiple endmember spectral mixture analysis: a case study in the city of Tampa, Florida. Geocarto Int 28:594-615.

https://doi.org/10.1080/10106049.2013.764355

White WA (1970) The Gulf Coastal Lowlands. In: The geomorphology of the Florida peninsula. Florida Bureau of Geology, Tallahassee, pp 142-155

\section{Figures}




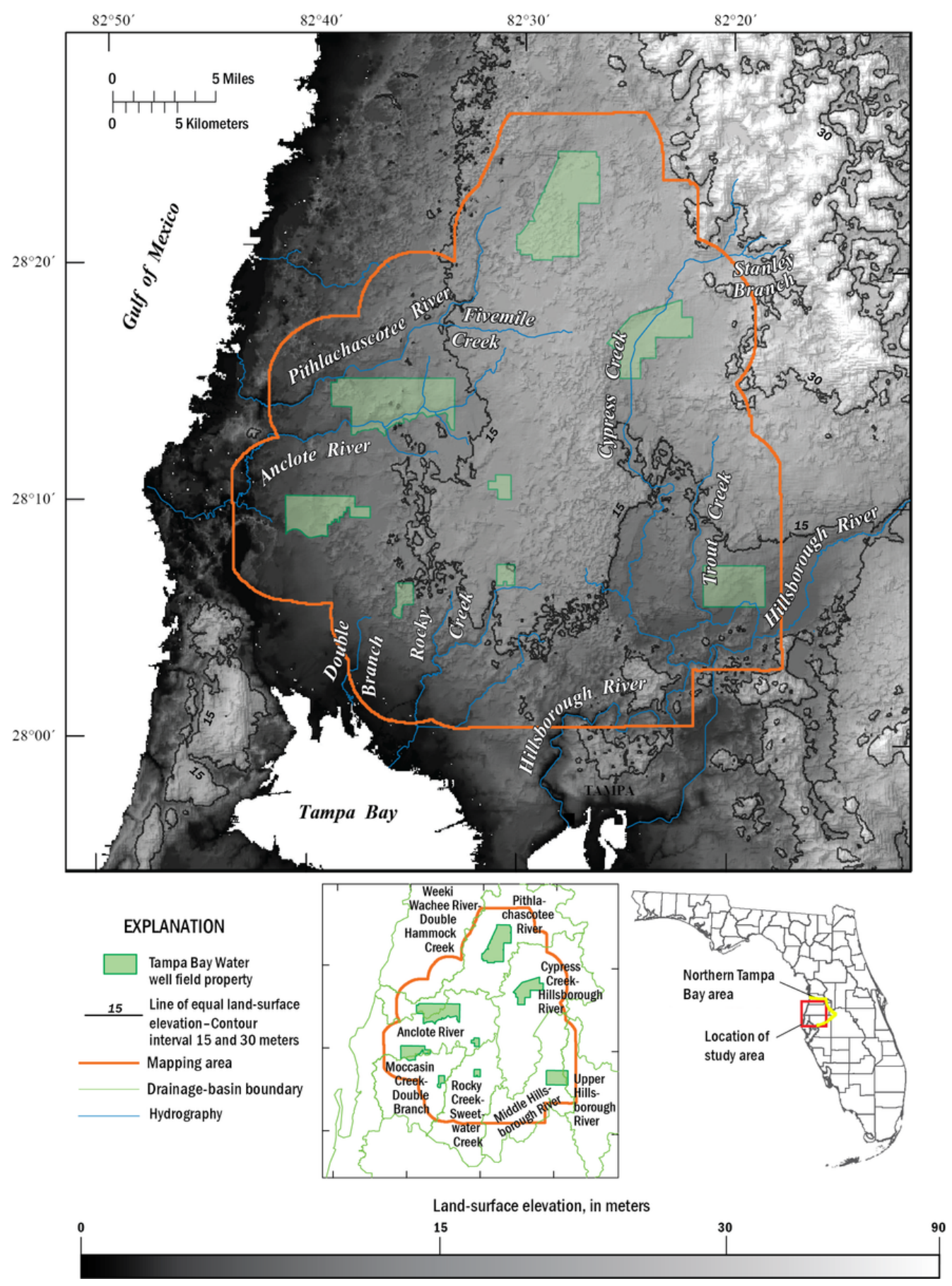

Figure 1

Map of the study area showing terrain, streams, stream drainage-basin boundaries, well field properties, and potentiometric-surface mapping area from Lee and Fouad (2017). Note: The designations employed and the presentation of the material on this map do not imply the expression of any opinion whatsoever on the part of Research Square concerning the legal status of any country, territory, city or area o bbnhjr of its authorities, or concerning the delimitation of its frontiers or boundaries. This map has been provided by the authors. 


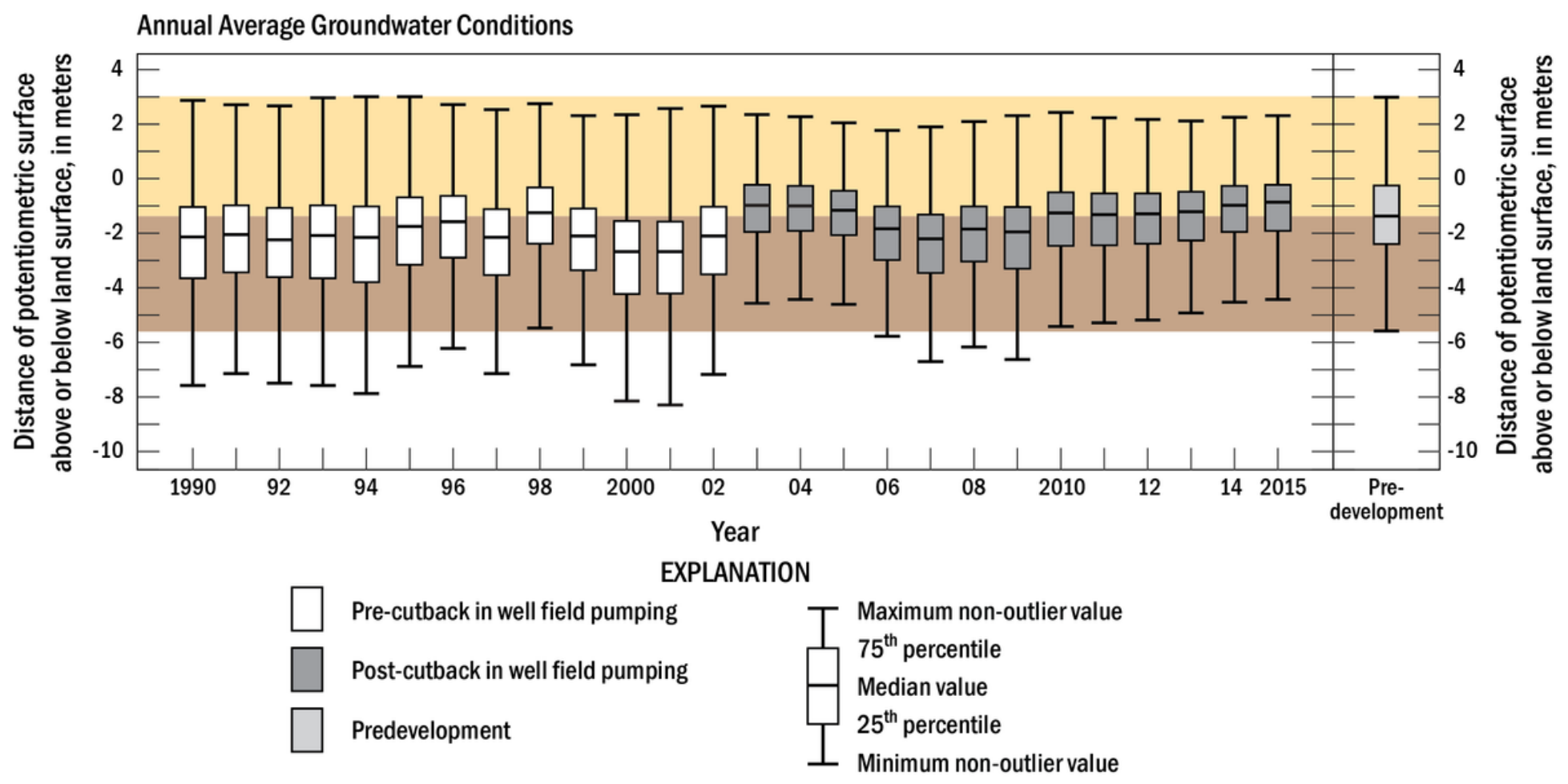

Figure 2

Box and whisker plots of annual average groundwater conditions in 10,516 wetlands in the study area from 1990 to 2015. Groundwater conditions in the wetlands are also shown based on the simulated steady-state predevelopment potentiometric surface of Bush and Johnston (1988) 


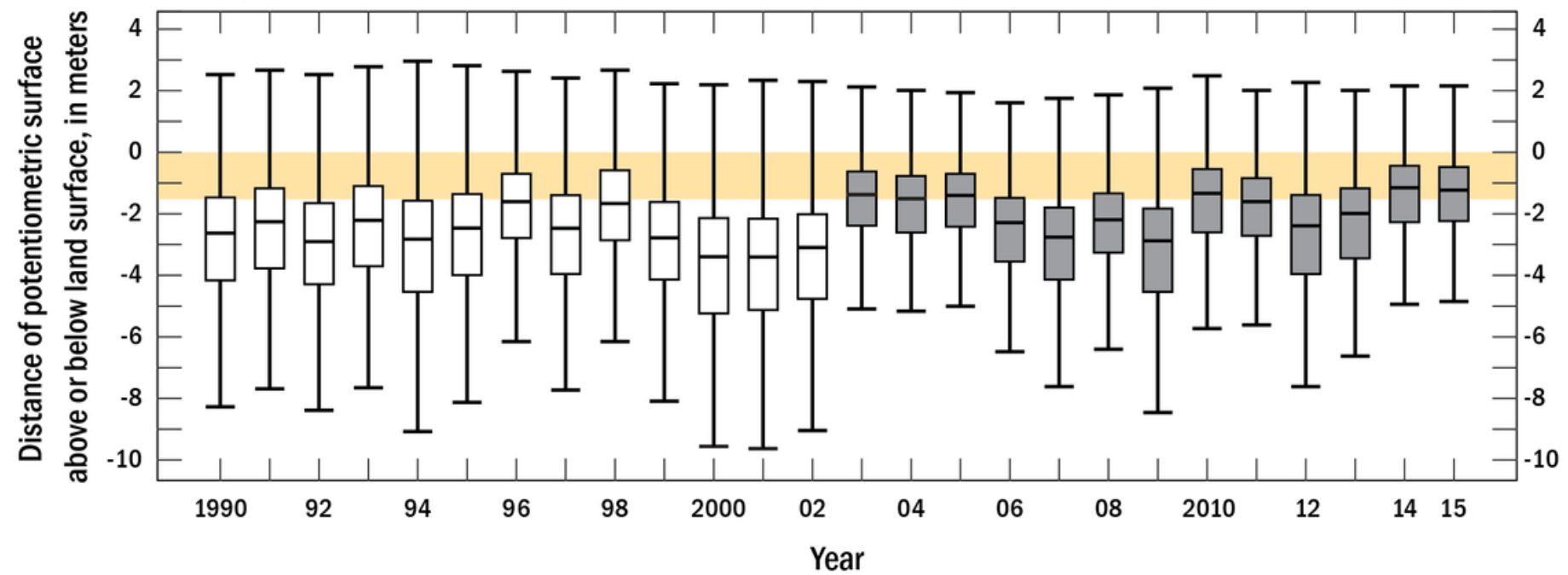

b September Groundwater Conditions

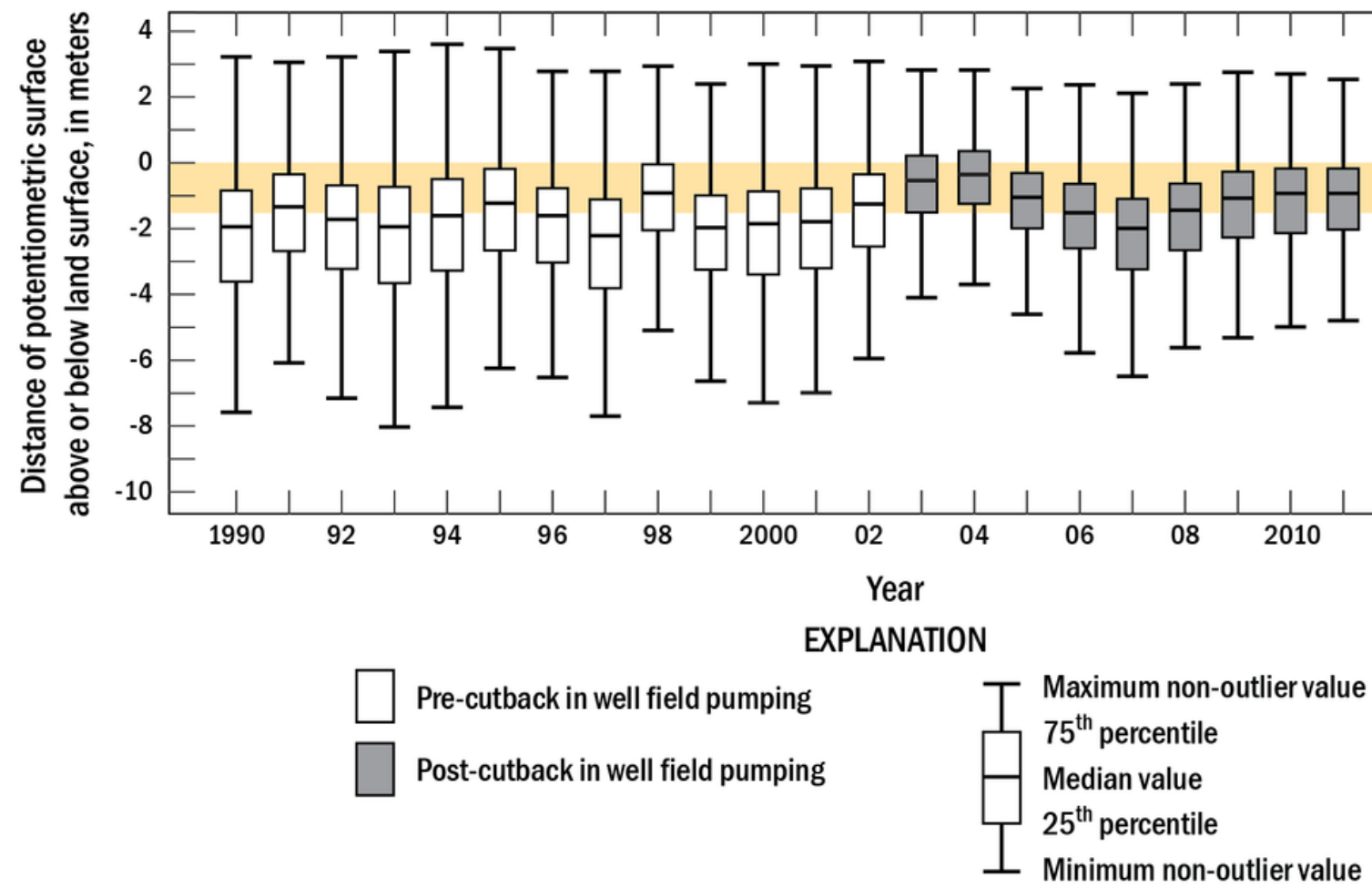

Figure 3

Box and whisker plots of (a) May (dry season) and (b) September (wet season) groundwater conditions from 1990 to 2015 in 10,516 wetlands in the study area. A shaded band from 0 to 1.524 meters (5 feet) below land surface is provided to help visually compare yearly variation in groundwater conditions 
a Annual Average Groundwater Conditions
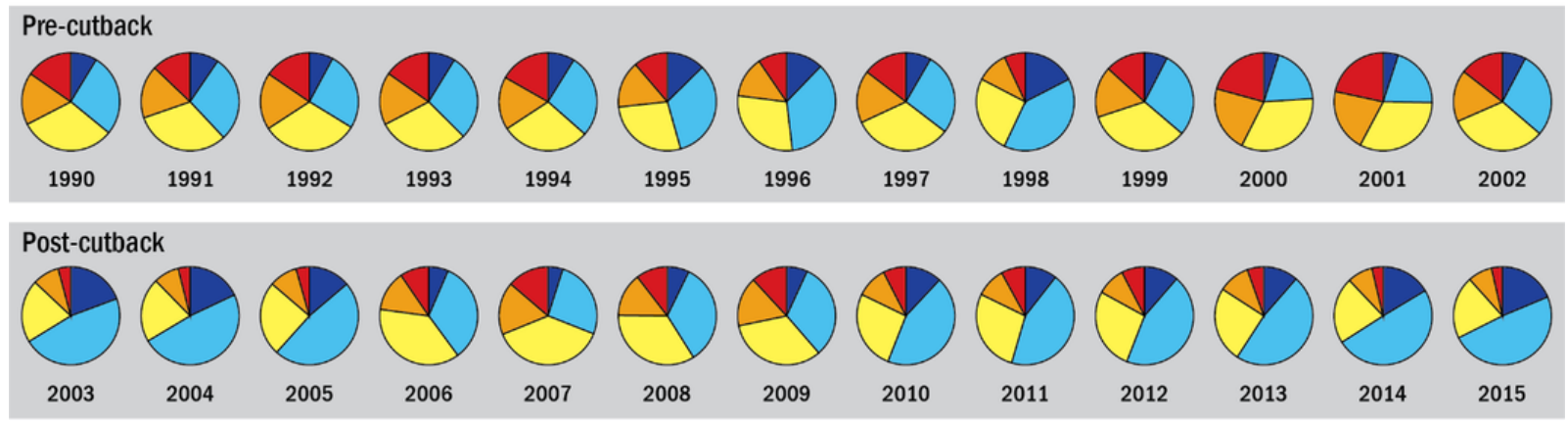

b May Groundwater Conditions
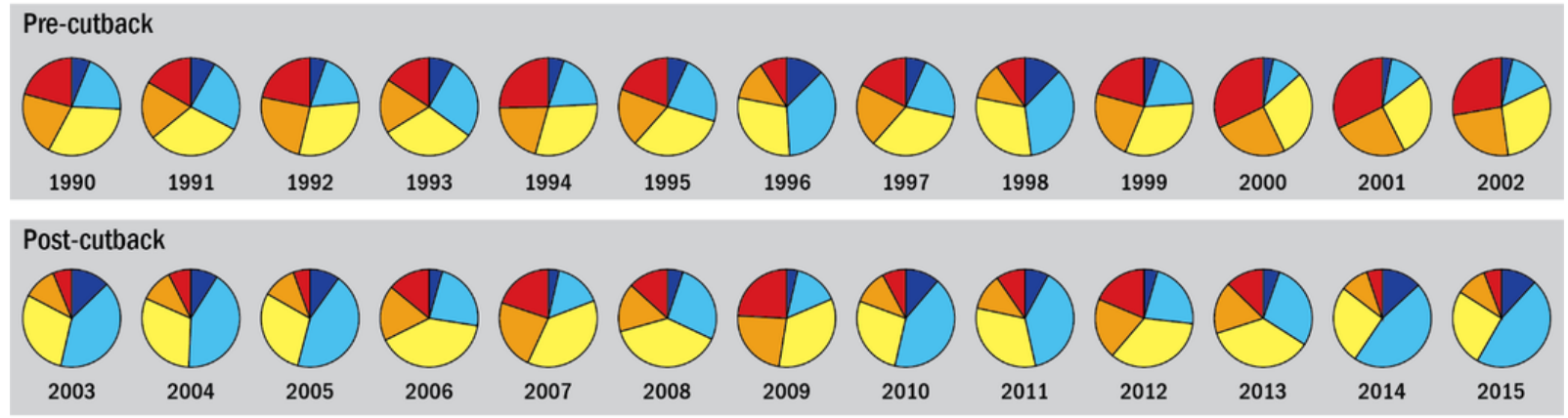

c September Groundwater Conditions
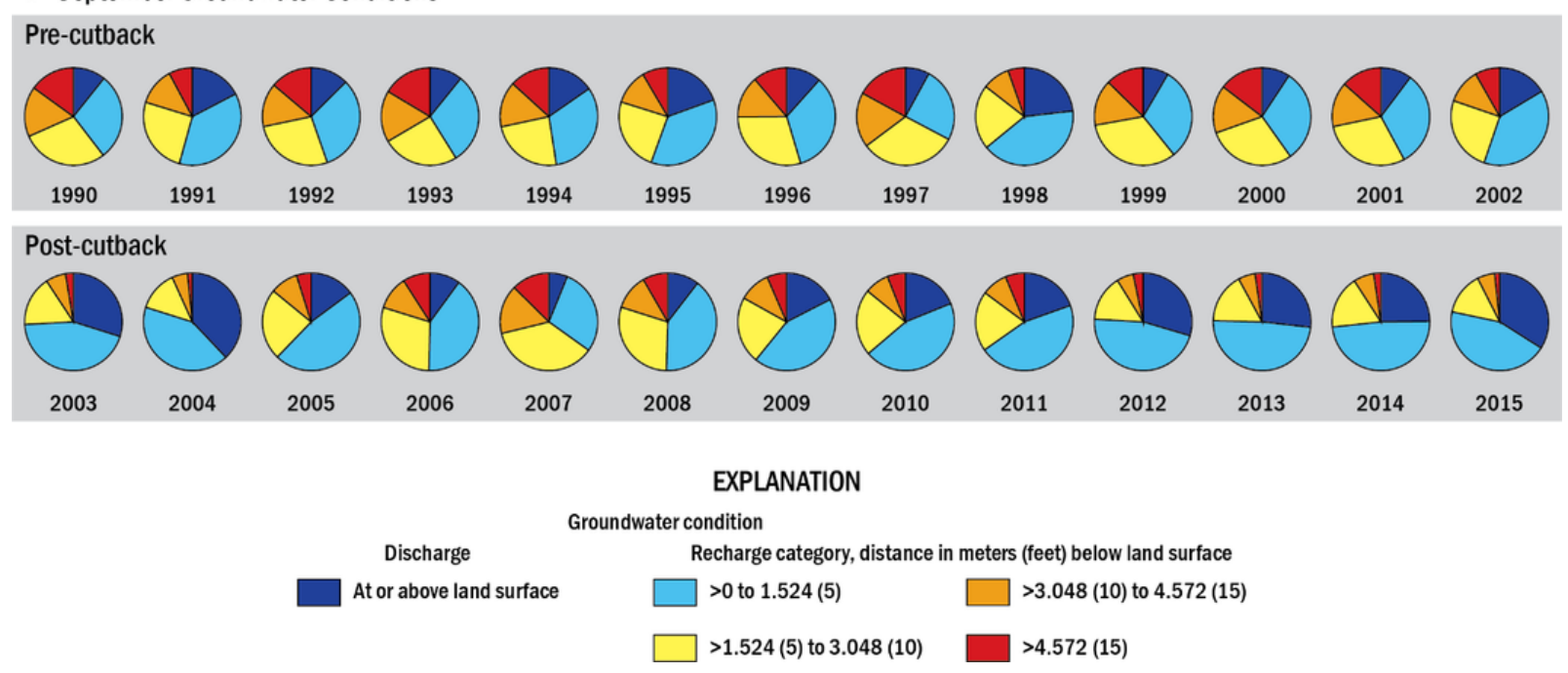

Figure 4

Pie charts illustrating the percentage of 10,516 wetlands in groundwater condition categories based on (a) annual average, (b) May (dry season), and (c) September (wet season) data from 1990 to 2015 
a Pre-cutback Average Annual Groundwater Conditions

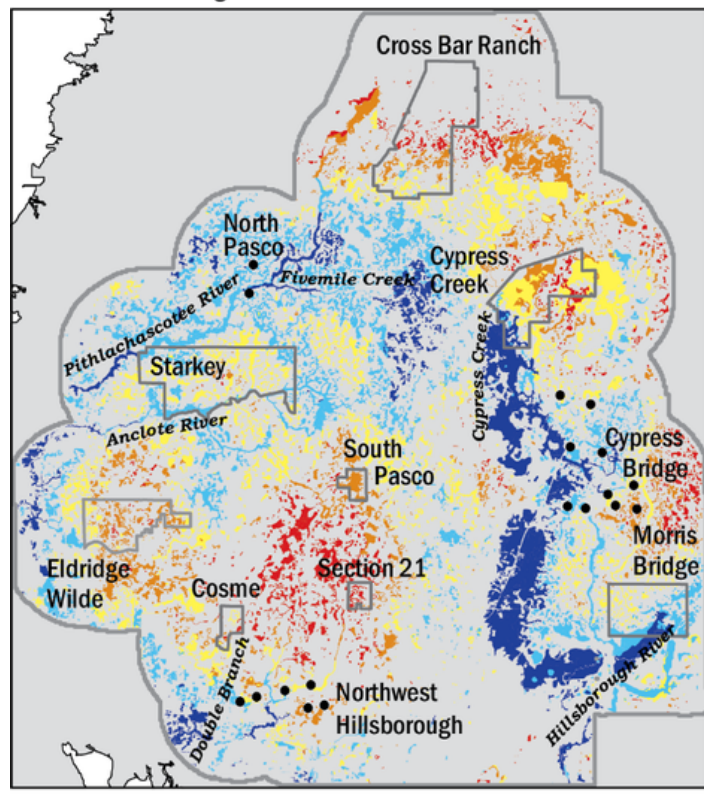

\section{EXPLANATION}

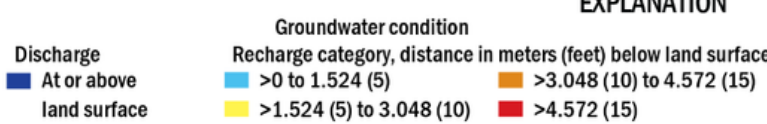

land surface $\square>4.572(15)$

c Predevelopment Groundwater Conditions

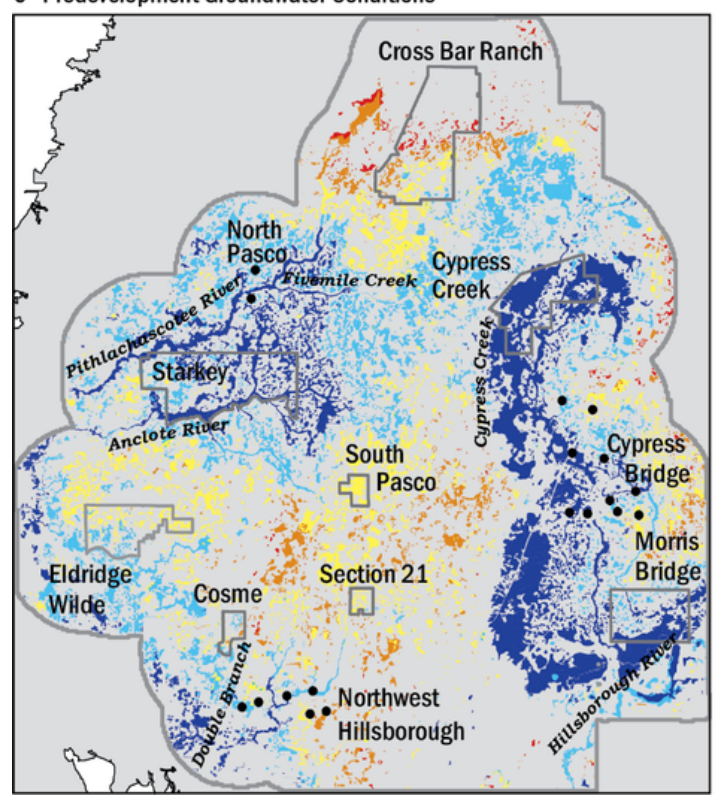

\section{Figure 5}

Maps of wetland groundwater condition categories in 10,516 wetlands (a) before and (b) after groundwater pumping cutbacks, and (c) in the absence of groundwater pumping based on a predevelopment potentiometric surface from Bush and Johnston (1988). Note: The designations employed and the presentation of the material on this map do not imply the expression of any opinion whatsoever on the part of Research Square concerning the legal status of any country, territory, city or area o bbnhjr of its authorities, or concerning the delimitation of its frontiers or boundaries. This map has been provided by the authors. 
a Pre-cutback May Groundwater Conditions

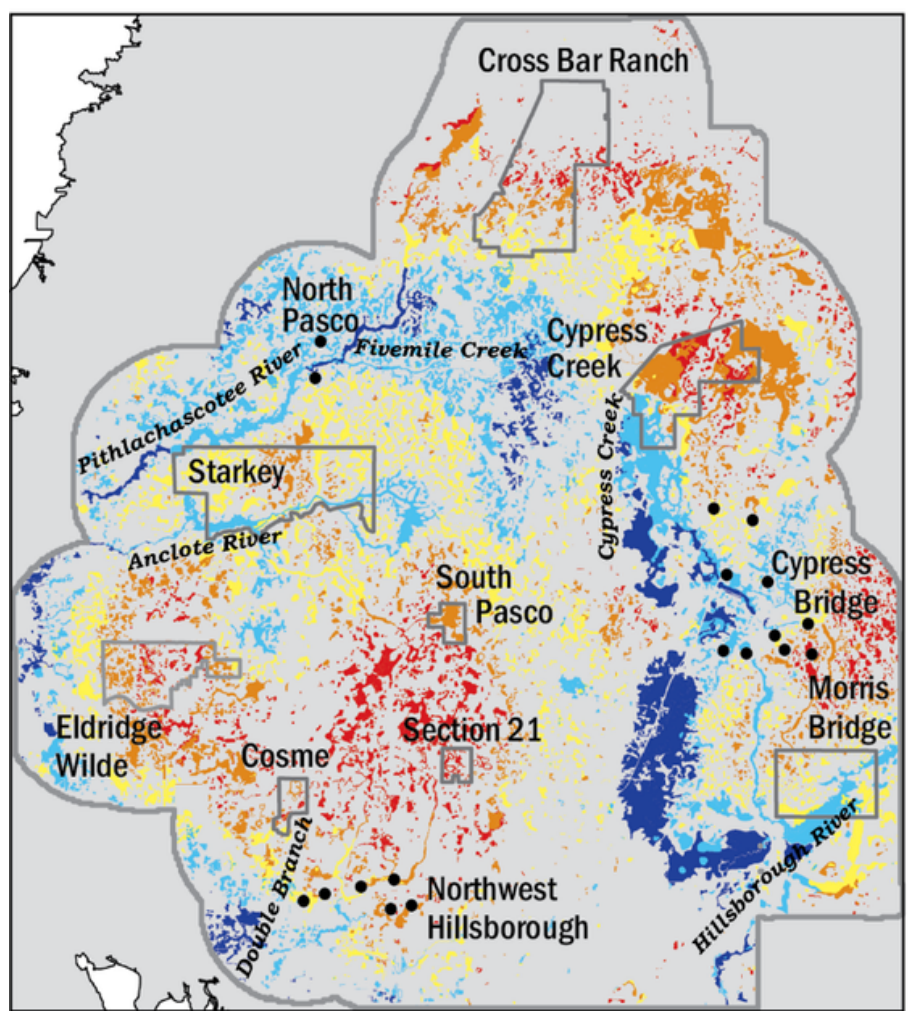

EXPLANATION

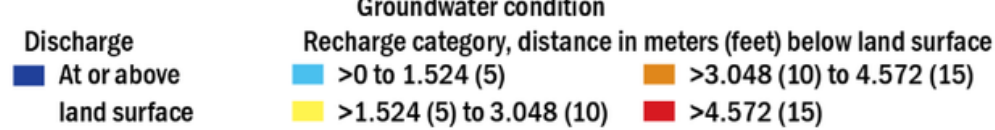

b Post-cutback May Groundwater Conditions

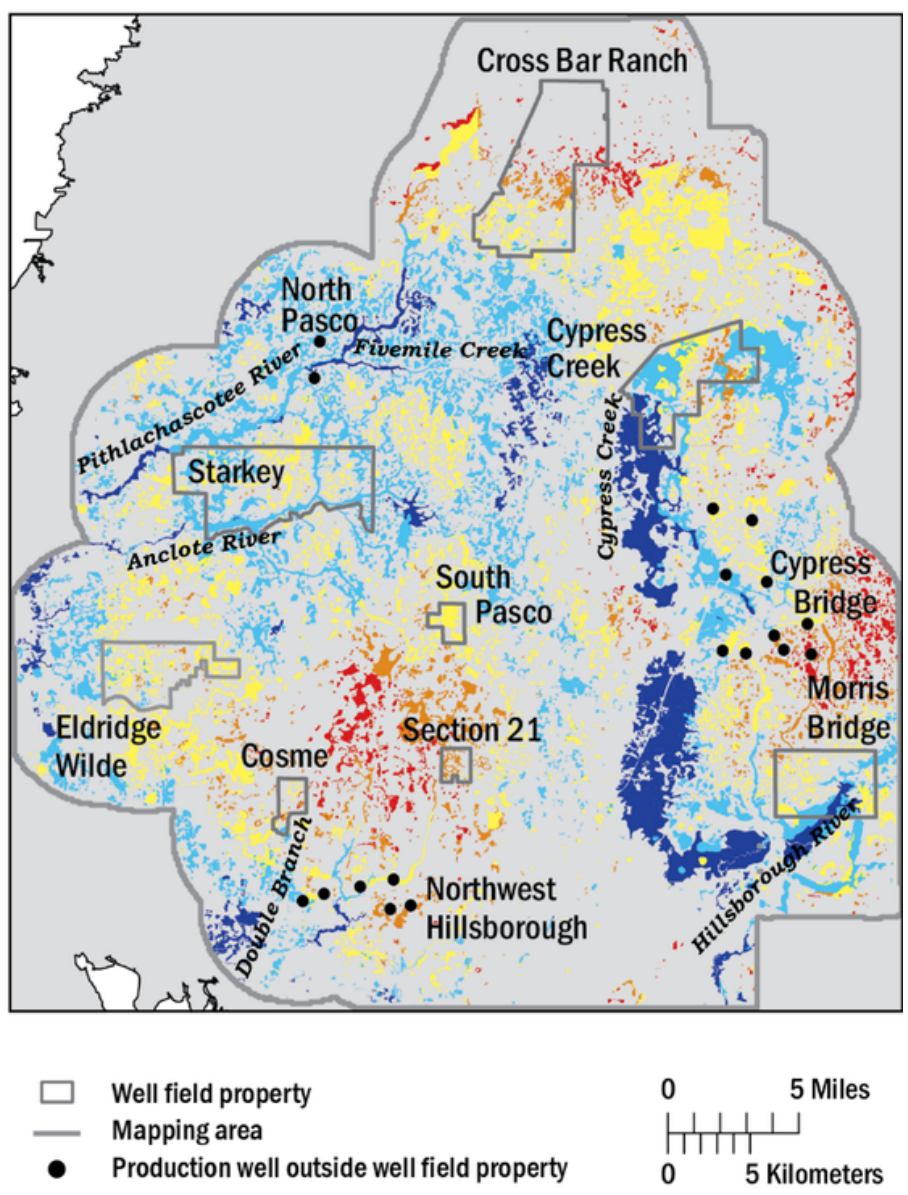

\section{Figure 6}

Maps of wetland groundwater condition categories in May (dry season) for 10,516 wetlands (a) before and (b) after groundwater pumping cutbacks. Note: The designations employed and the presentation of the material on this map do not imply the expression of any opinion whatsoever on the part of Research Square concerning the legal status of any country, territory, city or area o bbnhjr of its authorities, or concerning the delimitation of its frontiers or boundaries. This map has been provided by the authors. 
a Pre-cutback September Groundwater Conditions
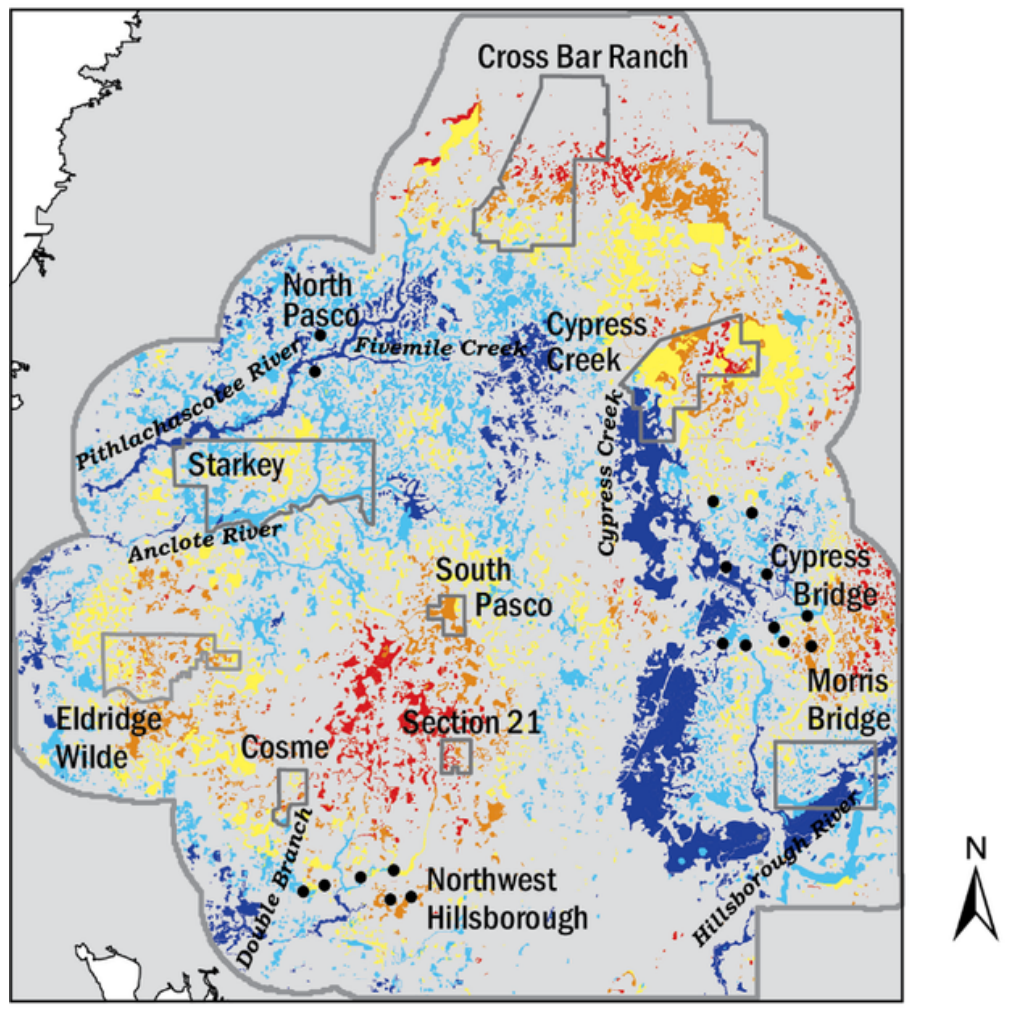

EXPLANATION

\section{Discharge}

- At or above land surface
Groundwater condition

Recharge category, distance in meters (feet) below land surface

$>0$ to $1.524(5)$

$>1.524(5)$ to $3.048(10)$
$>3.048(10)$ to $4.572(15)$

- $>4.572(15)$ b Post-cutback September Groundwater Conditions

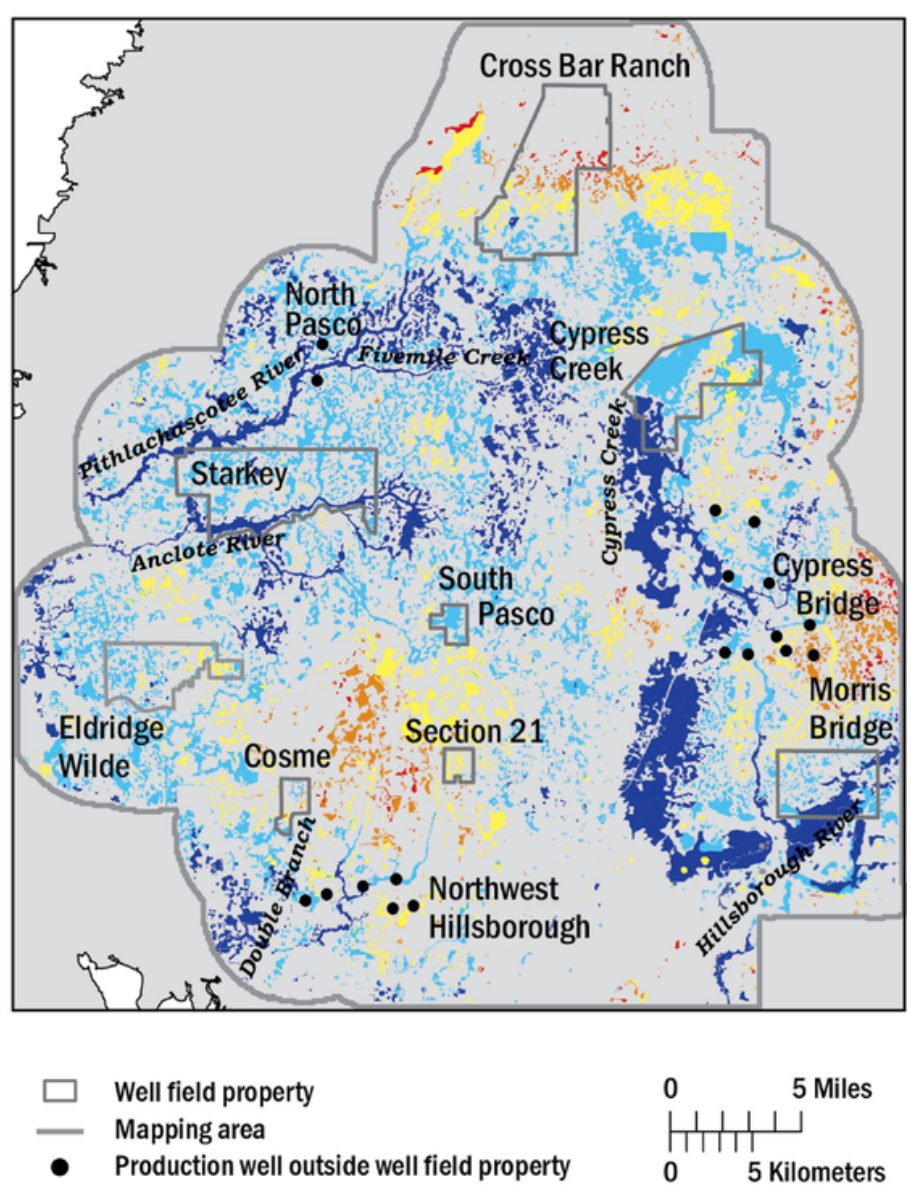

Figure 7

Maps of wetland groundwater condition categories in September (wet season) for 10,516 wetlands (a) before and (b) after groundwater pumping cutbacks. Note: The designations employed and the presentation of the material on this map do not imply the expression of any opinion whatsoever on the part of Research Square concerning the legal status of any country, territory, city or area o bbnhjr of its authorities, or concerning the delimitation of its frontiers or boundaries. This map has been provided by the authors. 